\title{
Problem Based Learning Model With Science Props To Enhancing Students' Science Process Skills And Cognitive Learning Outcome
}

\author{
Erwinsyah Satria
}

Elementary School Teacher Education Program, Faculty of TeacherTraining and Education,Bung Hatta University, Padang

\begin{tabular}{l} 
Article info \\
\hline Keywords: \\
Problem Based Learning, \\
Model, \\
Science Props, \\
Science Process Skills, \\
Cognitive Learning Outcome
\end{tabular}

Corresponding Author:

erwinsyahsatria.rr@gmail.com

\begin{abstract}
This classroom action research was motivated by the students' low science process skills and cognitive learning outcome in natural science. One of the reasons is the lack of teachers' ability in choosing appropriate learning model and using of science props in natural science learning. Thus, the implementation of Problem Based Learning model with science props to students of class IV SD Negeri 15 Surau Gadang Siteba Padang is one of the ways to solve this problem. The objective of this research is to describe the improvement of the students' science process skills and cognitive learning outcome in natural science at class IV at SD Negeri 15 Surau Gadang Siteba Padang by using Problem Based Learning model with science props. The instruments of this research were the observation sheets of students' science process skills and teachers' activities and the test sheets of students' cognitive learning outcome. The results showed that there was a significant improvement of students' science process skills and cognitive learning outcome in natural science class IV by using Problem Based Learning model with science props from the first cycle to the second cycle..
\end{abstract}

\section{INTRODUCTION}

Advances in science and technology had an impact on the development of education and learning in elementary school. Along with advances in information technology, education and learning also efforts change to be better. Education can be defined as a process of changing learners' behavior and attitude to become independent human beings and part of a community who can adapt with their environment [1]. Qualified education will involve children to actively learn from any resources. Teachers are functioned to facilitate learners in teaching process that they possess good learning outcomes and life skills needed by the students in their life settings. The children's potentials, skills and creativity can be well-developed when teachers realize that using varied teaching approach may motivate learners to study. Learning outcomes will be obviously improved when contextual teaching and learning process is conducted and the availability of teaching media or props is guaranteed.

Learning is defined as the activity or process of gaining knowledge or skill by studying, practicing, being taught, or experiencing something. Learning is also defined as the act of acquiring new, or modifying and reinforcing, existing knowledge, behaviors, skills, values, or preferences and may involve synthesizing different types of information [2]. Learning is also defined as process of interaction between students with teacher and learning sources on a learning environment [3].

Learning science at elementary school require students able to analyze the problem to do their own investigation. Natural science is related to investigation, finding, solving problems and understanding the surrounding scientifically and systematically through observations. This subject is not merely about mastering factual knowledge, concepts, or principles but also finding process that it will develop learners' scientific concepts, process skills and attitude. Problem solving skill is one of important thinking skills for students in science learning. Students which problem solving skills will be able to identify problems, create experiment design, do experiments independently in groups, and communicate their results of solution to their classmate. 
Understanding concepts, investigating and solving problems by the students will be easier to do if teacher supply or exhibit props, tools or equipments in learning science. Props are something that give special attention to students for understanding something learn. Props are something that use to communicate learning materials in order learning process take place.

Most learning natural science in West Sumatera still conventional, use lecture and askanswer method. Based on interview and observation to the teacher class IV at SD Negeri 15 Surau Gadang Siteba Padang, she state that generally natural science learning science learning is dominant by the teacher role than students, because time and space to do their own observation and investigation to solve the problems is limited, so the science process skills and natural science learning outcomes is not reach fully by students (only $26 \%$ of the students who were able to achieve the score above the Minimum Standard Score). Teachers skills and knowledge still does not meet the expectation that students cannot complete the learning objectives stated in learning instruction. Another issue is that the teachers mostly do not make use of teaching and learning media or props. There are some reasons why this happens; laziness and bothered of the teacher preparing media or props for learning, teachers' lack of understanding and skills in using the props and teachers' reluctance to train themselves in using the media or props.

Based on the observation it can be concluded that learners' low learning outcome in subject of natural science caused by the lack of optimality of learners science process skills and science props. The teachers should stimulate the students to actively use their science process skills to solve the problems in learning process through making use of props in their science class. One of the approaches that could improve learners' science process skills and elevate their understanding of scientific concepts and principles is Problem Based Learning (PBL) model using science props.

Science props is making used that the teaching and learning process through PBL model enable to motivate learners that they actively use their science process skills in conducting an experiments, observation and problem solving. PBL model ia a model that is used science process skills to facilitate the students to construct their own knowledge that stimulus by the problem. This approach is believed to be enhancing student's selflearning ability and enjoyable that all concepts and materials will be saved in learners' long term memory or in other words, the learners will always remember the concept taught by the teachers through the use of science props. This approach is expected to reduce students' boredom of learning their classroom. This will be a factor that might influence learners' learning outcome which has been determined in the objectives of teaching. Science process skills are some steps used by scientists in conducting their researches. A scientist should possess some skills that enable him/her to conduct a research namely: observation, measurement, questions, making a hypothesis, classification, guessing, interpreting data, presentation, experiment, etc.

\section{Natural Science}

Natural science is a collection of systematic theory, it's application generally limited on natural phenomenons, born and develop by scientific method like observation, and experiment, also involve scientific attitude as curiousity, open minded, honest, etc [4]. Natural science is human being effort in understanding universe through observation right on target, using procedure, and explain with logical thinking so derive a conclusion [5].

Natural science is expected to become a vehicle for the students to learn themselves and their physical surroundings. It is also objected that learners' are able to implement their knowledge in their real life. Natural science learning process is emphasized on giving direct experiences that the expected competencies can be developed. There are some objectives of subject of natural science in elementary schools determined by National Education Assurance Board in KTSP [6]. It is to develop learners' knowledge and understanding of scientific concepts which are beneficial and applicable in daily life basis. Moreover, it is expected that learners' curiosity, positive attitude and awareness are elevated that they understand that science is mutually related to learners' environment, technology, and community. It is objected that learners' are able to expand their science process skills to study their physical surroundings, to solve problems and to find the 
solution of problems. Last, but not the least, it is expected that learners will possess the knowledge, concepts and skills of Natural Science as one of the basis for their advanced level of education (SMP/MTs).

\section{Problem Based Learning Model}

To achieve the objectives of the science subject, it is highly recommended that teachers should pay a massive attention to appropriate model, approaches, learning strategies, and learning props or media and infrastructure that must support teaching and learning processes.

Problem based Learning (PBL) is based on the thinking that every individual form their understanding through their life experiences [7]. This inquiry learning method requires students to get and process the new information in the suitable way of real or nature brain process. Learning science through PBL is a learning process which is started from problems which are found in the environment . Through PBL the students not only learn about the abstract concepts but also learn how to apply it in their real life environment. Therefore, it's hoped that the students have good ability in understanding materials holistically. In PBL model, students are given problems, and then in group they will try to solve the problems. To solve the problems, the students need to find information from various sources. The problems are formed in order that the students could find their learning need through solving the problems.

The steps below give guidelines for teachers to apply the PBL.

Step 1. The teacher begins the PBL process through developing real world, open, and problems without solutions. Those problems are related to learning material.

Step 2. After the teacher chooses the problems holistically, they have to think of the ways in which the students use the different research method and tools to find the solution for the problems. The teacher presents the problems for their students.

Step 3. After presenting the problems, the students could begin their research. The teacher could help students to begin it through providing them with some web site lists which are appropriate or learning sources which could prove it. after that, the students do the research, plan their strategies, form the hypothesis, collect information, doing experiment and find the solutions.

Step 4. Developing and presenting students' report with helping by the teacher. The teacher help students sharing their task with others.

Step 5. Analysis and evaluation problem solving process. The teacher help students doing reflection or evaluation about their investigation and processes that they used.

Through the steps of PBL, the students could understand and solve the problems which are given in learning process. Then through PBL steps the students could comprehend the knowledge and get real experiences so that it can increase students' science process skills and learning outcome.

\section{Science Props}

Prop is component of learning sources at student environment which could arouse students for learning. Prop is physical space vehicle that contain learning material. So prop is something that used to communicate learning materials in order learning process occure. Props as helping tool in learning have function to clarify, facilitate students understanding the concepts or principle or theory, and make curriculum' message will be deliver to students more interesting, so could increase learning motivation of the student and increase effectiveness and efficiency of the learning process [11].

Generally, props as educational medium betwixt include as follows; (1) printed materials e.g.: book, magazine, charta, photo, card, poster, (2) media audio visual e.g.: computer, VCD, DVD, TV, hand phone, audio visual card, slide, radio tape, cassette recorder, (3) things in daily life e.g.: lamp, balance, spring, rubber band, battery, magnet, pulley, scissor, shovel, lever, wedge, gear etc.

Application of science props needed it most in natural science learning that use science process skills, so learning will be more meaningful for the students. The role of science props 
between it could: (a) activate communication and interaction between teacher and and student and between students in learning, (b) arouse mind, feeling, attention, and desire of student in learning so give learning experience more meaningful fo students, (c) activate student' wish and learning interest, (d) building basics for learn development, so make science material saved in learners' long term memory longer, (e) giving real experience that could raise students independent [11].

\section{Science Process Skills}

It is undeniable that scientific skills, or more specifically science process skills such as observing, hypothesizing, conducting experiments, interpreting data, communicating and so on are among the ingredients to produce scientific society [12]. Scientists do not use a specific, step-bystep method in their research but through several ways to approach a problem [13]. The compilation of all these skills is what we call "science process skills" which are always associated with scientific inquiry [12]. Different researchers provide different sets of skills that are to be included in science process skills. Six process skills - observing, inferring, communicating, classifying, measuring and experimenting [14]. However, the more common definition of science process skills contains two levels of skills - the basic skills and the integrated skills [15]. Again, researchers have different views when it comes to categorizing the skills into these two subcategories. Despite the differences in categorization, the following is a set of science process skills agrees by all the authors: Observing, Classifying, Predicting, Using numbers, Measuring, Inferring, Interpreting data, Controlling variables, Hypothesizing, Defining operationally, Experimenting. The learning of science among students is greatly influenced by the mastery of science process skills [16].

\section{Learning Outcomes}

Learning outcome is measure repel to see student' success in mastering learning materials that deliver during learning process. Learning outcomes is changing in behaviour as a result of learning activities in broad understanding cover up domain cognitive, affective, and psychomotor . Educational goals in the formulation of the national education system using the classification of learning outcomes of the revised Bloom. In this study the learning outcomes measured only in cognitive domain aspect given and understanding.

Cognitive domain with respect to the results of intellectual learning that consist of six aspects, as follows:

(1) Given (C1): to capture relevant knowledge from long term memory.

(2) Understanding (C2): build understanding based instruction either orally, writing or in the form of reading the chart.

(3) Apply (C3): use or apply the procedure of creating a situation.

(4) Analyze (C4): solve material into the principal portion and determine the part and connect with others.

(5) Evaluate (C5): making a decision based on a criteria and standards.

(6) Creating (C6): gives a lot of elements to form an overall coherence or functionally into a new pattern or structure.

At elementary school only three cognitive aspects evaluation apply in student learning.

\section{RESEARCH METHODOLOGY}

This study is classified into Classroom Action Research which was conducted in two cycles. Each cycle consisted of planning, acting, observing, and reflecting. This research was conducted at SD Negeri 15 Surau Gadang Siteba Padang, West Sumatra. The subjects of the research were 23 students; 8 female students and 15 male students in grade four. This research was conducted collaboratively in four meetings. It was started from January 2016. The sources of the data were the teachers and the students who were involved directly in the learning process. The data were obtained from the results of observation on the implementation of Problem Based Learning model assisted with Natural Science props and observation on the students' science process skills, and learning achievement test. There were two observers involved in this research. The data were gathered through observation, and learning achievement test. The data gathered were analyzed by using qualitative and quantitative models. 
The complete procedure of action research could be described as follows. In the planning stage, there was a discussion held with the teachers and the principal to decide when the research would be carried out, to determine the materials to be taught in this research, to design the Lesson Plan with the teacher teaching in the fourth grade, to prepare tools, to prepare Natural Science props and instructional media, to practice teaching by using Problem Based Learning model assisted with Natural Science props, to design exercises for each meeting, to explain the way to use observation instruments to the teacher and the observers. Either the researcher or the observers recognized the students' names. They worked together to arrange study groups and assignments for the students, write students' workbooks, observation sheet and learning achievement test. He also prepared camera for documentation purposes during the research and explained to the observers what should be documented.

In the action phase, the researcher applied Problem Based Learning model assisted with Natural Science props. It started with the teacher building positive relationship with the students so that they were motivate to learn. The teacher then raised the students' learning interest by displaying pictures about the materials to be learned. The teacher made a linkage between the new materials with the students' real life interestingly and pleasantly. The teacher asked the students to do investigation activities related to the materials of the meeting by using Student Worksheet and Natural Science props provided in groups. The teacher helped the students to actively find and construct their own knowledge and make use of their science process skills in various ways. After all of the groups completed the activities, the teacher asked one of the groups to present their work in front of the class, while teacher and the rest students gave evaluation and flashback. The teacher encouraged the students to learn. At last, the teacher and the students celebrated their success in that meeting. During the learning process, the teacher facilitated, gave direction and guidance to the students. Meanwhile, their learning achievement could be identified through learning achievement test administered at the end of each cycle.

Observation was done by two observers through which they observed the students' scientific skills and the implementation of Brain Based Learning approach assisted with Natural Science props during the learning process. The implementation of this approach and the students' scientific skills were recorded on the observation sheets. The observations were carried out intensively, objectively, and systematically. During the observation, the researcher and the observers tried to recognize and record the changes occurred over the students and the teacher in the learning process of Problem Based Learning model assisted with Natural Science props; was it better or worse? The science process skills of the students which were observed were: doing observation, doing experiment and communicating. These observations were continuously conducted from cycle I to cycle II. The results of the observation in cycle I could be used as the basis for doing action in the next cycle. The results were discussed with the observers as a reflection for the following plan. At the end of each cycle, a test was given to the students in order to know their cognitive achievement in the level of knowledge and comprehension.

Reflection is held at the end of every action. On this stage, the researcher and the observers discussed about the action taken. The materials discussed were the reflection of the result achieved in Natural Science learning process which was related to the students'science process skills, their cognitive learning achievement, and the teacher's activities after the learning process, the disparities between the plan and the action carried out, and the conclusion for the data obtained. These data were used as the consideration for the next action. The result of the reflection was needed to see the accomplishment of the indicators. If the achievement indicator in cycle I had been reached, the cycle was stopped in cycle II. However, it would be continued to the next cycle if the achievement indicators were not yet achieved. In the discussion stage, the weaknesses of each cycle were brought into a discussion, as well as to find out the solution of the problems and to do improvement in the next cycle. It was done based on the results of the observation and evaluation.

The results of the test were analyzed qualitatively by calculating the average score of the class and the percentage of the students who had achieved the score above the Minimum Standard Score namely $75 \%$ of the students obtained 75 or more out of 100 . The results of the observation were analyzed by counting the scores, the average scores, and the percentage of the indicators of each activity carried out compared to the total activities and the total number of students. 


\section{RESULTS AND DISCUSSION}

\section{Cycle I}

In cycle I, the learning materials were about Force. The materials delivered in the first and second meeting of cycle I were "Forces cause changing motion of moving object and Forces could changing the shape and size of an object" and "Types of forces". They were taught to the students by using Problem Based Learning model assisted with science props like book, ball, can, sailboat toy, spring magnet, bottle, and ball bearing. The time allocated for each meeting was $2 \times 35$ minutes. The results of the observation on the treatment given were as follows.

\section{The Result of the Observation on the Students' Science Process Skills}

The result of the observation in Cycle I toward the development of learners' science process skills during the teaching and learning process though Problem Based Learning model by using science props is described in Table I.

Table 1. The Students' Science Process Skills in Cycle I

\begin{tabular}{|l|l|c|c|c|}
\hline \multirow{2}{*}{ No } & \multirow{2}{*}{$\begin{array}{c}\text { Indicators of Science } \\
\text { Process Skills }\end{array}$} & \multicolumn{2}{|c|}{ Meeting } & Averag \\
\cline { 3 - 4 } & Procing & $43.5 \%$ & $60.9 \%$ & $52.2 \%$ \\
\hline 1. & Observing & $43.5 \%$ & $60.9 \%$ & $52.2 \%$ \\
\hline 2. & Experimenting & $43.5 \%$ & $66.7 \%$ & $53.1 \%$ \\
\hline 3. & Communicating & 4 & \\
\hline
\end{tabular}

The Table I indicates that:

a The students' science process skills in doing observation increased slightly from meeting 1 to meeting 2 . The percentage of the students who were able to do this activity was $60.9 \%$ or 14 students in the second meeting. It's showing that almost half of the students were able to do observation in groups based on the tasks given. However, there were still many students who were not able to do observation (on guiding group investigation phase), they instead looked confusedly at the activities done by their friends. This was caused by the students who did not understand about what should be observed and they were not accustomed to Natural Science learning process of Problem Based Learning model assisted with science props. In addition, the students had lack of understanding on the assignments contained in the Student Worksheet. The teacher also gave less guidance and motivation to the students to do observation on experimenting Forces required in the Student Worksheet.

b. The improvement of the students' science process skills in the indicators of doing experiment in the second meeting was also still low. The number of the students who were able to do this activity was 14 students in the second meeting. Many of student still unwilling to do this. The students' lack of understanding on the instructions given in the Student Worksheet was assumed as the cause of the problem. Many of the students also felt afraid of doing experiment of Forces properties. Furthermore, some of them used the learning props as toys. Meanwhile, the teacher also given less guidance and motivation to the students doing the experiment for the learning process.

c. The students' science process skills in communicating the learning activities in cycle I was also still low. This result showed that many students did not understand about the learning materials and the activities being done. The number of the students who were able to do this activity was 15 students in the second meeting.. This number suggests that there were only a half of the students who were able to deliver or write the result of their observation on the Student Worksheet, and there was also similar number of students who were able to draw conclusion about properties of Forces. A large number of students were also unable to see the application of Forces properties in their daily life.

In cycle I, it seemed that many students were not able to perform science process skills as the learning model applied by the teacher was different from the previous ones. They were not accustomed to such approach and did not understand what they should solved in the learning posted by the teacher. The students were also not accustomed to their new teacher. 


\section{The Students' Cognitive Learning Outcome}

The result of the test in cycle I at third meeting revealed about the students' learning outcome about Forces materials, the number of the students who were able to achieve the Minimum Standard Score, the number of the students who were not able to achieve the Minimum Standard Score, the students' average score and the percentage students' learning mastery classically. The results were presented in Table II.

TABLE I. The Students' Cognitive LeARning Outcome In CyCle I

\begin{tabular}{|l|l|c|}
\hline $\begin{array}{c}\mathbf{N} \\
\mathbf{0}\end{array}$ & \multicolumn{1}{|c|}{ Description } & Total \\
\hline 1. & $\begin{array}{l}\text { The number of students who were able to achieve the score } \\
\text { above the Minimum Standard Score }\end{array}$ & 16 \\
\hline 2. & $\begin{array}{l}\text { The number of students who were not able to achieve the score } \\
\text { above the Minimum Standard Score }\end{array}$ & 7 \\
\hline 3. & The students' average score & 76.6 \\
\hline 4. & $\begin{array}{l}\text { The percentage of the students who were able to achieve the } \\
\text { score above the Minimum Standard Score }\end{array}$ & $69.6 \%$ \\
\hline 5. & Target & $75 \%$ \\
\hline
\end{tabular}

From Table II, it was revealed that the students' cognitive learning outcome in cycle I was still low, and there were many students who were not able to achieve the score above the Minimum Standard Score. The number of the students who got score above the Minimum Standard Score was 16 indicating that the target of $75 \%$ students achieving the standard score was not yet achieved. This problem was trigged by the students who were not familiar to the learning process of Problem Based Learning model with Science props. The teacher was less skillful in guiding students, explaining how to solve the problem and giving reflection and evaluation of the learning materials during and on the end activity so that the students could not understand the learning that deliver by teacher and could not much memorize the materials. In the initial activity, the teacher rarely correlated the learning materials to the students' real experience which was concrete and easy to be understood. In the end activity, the teacher did not yet verify thoroughly whether the students had understood the materials or not. The students' science process skills which were low in observing, experimenting, and communicating the learning materials had made the students got low mastery/understanding on the materials being learned. Many of them were not able to answer questions in the test of the cycle I. The students' low learning outcome was also caused by the teacher who was not good at managing the time and class, stimulating the students to actively use their science process skills in the learning process. In addition, the teacher was not fully proficient in applying the steps suggested in Problem Based Learning model with Science props.

After the action stage and observation were done, reflection activity with the teacher and observers was carried out to discuss the results of the observation. The results of the observation revealed that the student did not have interest or faith that problem learnt hard to solve, they feel reluctant to try it. The teacher was still awkward/less proficient in conducting the steps suggested in Problem Based Learning model using science props. The teacher was not yet able to raise the students' learning motivation at the beginning to make them more active in using their science process skill in the learning process. The teacher needed to improve her ways of teaching in initial activity, in core activity, in end activity.

In order to increase the students' understanding, the teacher should guiding the students doing problem solving or experimenting using science props. The teacher was also required to stimulate the students to work actively by making use of science props provided for groups, and challenge them to interpreting. The teacher could give some helps especially to those who were shy and quiet. The teacher was also expected to guide the students in doing observation through the Student Worksheet which had been revised (accompanied by better pictures and instructions). In the next cycle, the teacher was expected to be more skillful/effective in making use of the time provided and to be able to explain the lesson more clearly by using pictures and props at initial activity. 
She was also demanded to give reinforcement in reflection stage. By doing such improvement, it was expected that there would be many students who were able to answer the questions in the test. The teacher was demanded to guide her students to think about the application of the learning materials in their daily life. To the two observers, it was expected to do observation well and carefully during the learning process.

\section{Cycle II}

Based on the reflection result in cycle I, a better planning was remade regarding the way the teacher taught by using the Problem Based Learning model with the Science props. The teacher was asked to do better classroom management and instructional time. She was also asked giving more motivation to students at the beginning of learning. The improvement was also made by making concept pictures with colors, and attractive words in order to create meanings for the students and help the teacher in explaining the concept to enable students to understand more easily and remember the material that they studied longer. A better planning on how the teacher explained the material was also done in the initial with using video and end activity by connecting the material to be taught with real-life experiences. It was helpful because the brain learned best from concrete experiences.

The teacher guided and motivated the students better in order to improve their will to observe, experiment, communicate during the core activity as well as when they performed inquiry activities. The teacher also intensively guided and facilitated the students who wanted to try and to be able to communicate what they had learned. After discussing with the teacher, it was found that other aspect that needed to be improved in cycle II was the worksheets. It was hoped that the worksheets would help the students to understand easily and be active in doing the observation and experiment. The way the teacher provided reinforcement to the students towards learning in the end activity was also improved. She checked whether the students were already familiar with the material they had learned or not, so that it was expected that a lot of them obtained satisfactory learning achievement in the final test.

In the implementation of the natural science learning activities in cycle II, the material being taught was "Heat and Sound Energy in first meeting and "Transfer of Heat Energy through Conduction, Convection, and Radiation" in the second meeting by using the Problem Based Learning model with Science props. The observation was carried out by two observers using observation sheets. The result of the observation showed that the teacher was successful in motivating and building a positive relationship with the students, in implementing the Problem Based Learning model, in presenting the subject matter by using pictures/video and giving concrete examples.

She was also successful in motivating and guiding the students to observe and solve the activities and things learned by using available worksheets and Natural Science props as well as guiding them in a group to communicate about their activities in the worksheets. She also succeeded in motivating and guiding groups of students in making observations and asking them to consider the applications of heat and sound energy in daily life by giving few clues. In addition, she checked her students' understanding about the material that had been taught and reminded them to read more material about Heat and Sound Energy and Transfer of Heat Energy at home at the end of the second meeting. Thus, the students would be able to pass the cycle II's final test. The full descriptions of students' increased activities in cycle II were as follows:

\section{The Result of the Observation on the Students' Science Process Skills}

Based on the data obtained, it could be observed that the development of students' science process skills in cycle II was in Table III:

Table III . The Students' Science Process Skills in Cycle II

\begin{tabular}{|l|l|c|c|c|}
\hline \multirow{2}{*}{ No } & \multirow{2}{*}{$\begin{array}{c}\text { Indicators of Science } \\
\text { Process Skills }\end{array}$} & \multicolumn{2}{|c|}{ Meeting } & \multirow{2}{*}{ Average } \\
\cline { 3 - 4 } & Observing & $\boldsymbol{1}$ & $\boldsymbol{2}$ & \\
\hline 1. & Obs.9\% & $91.3 \%$ & $82.6 \%$ \\
\hline 2. & Experimenting & $83.3 \%$ & $87.0 \%$ & $85.2 \%$ \\
\hline
\end{tabular}




\begin{tabular}{|l|c|c|c|c|}
\hline \multirow{2}{*}{ No } & \multirow{2}{*}{$\begin{array}{c}\text { Indicators of Science } \\
\text { Process Skills }\end{array}$} & \multicolumn{2}{|c|}{ Meeting } & \multirow{2}{*}{ Average } \\
\cline { 3 - 4 } & & $\mathbf{1}$ & $\mathbf{2}$ & \\
\hline 3. & Communicating & $83.3 \%$ & $87.0 \%$ & $85.2 \%$ \\
\hline
\end{tabular}

The data in Table III could be interpreted as follows:

a. There were $91.3 \%$ or 21 students who had been actively involved in doing observation at the end of the second meeting of Cycle II. They were able to describe Heat transfer. The students got much guidance from the teacher to actively observe experiment and investigation activities to solve the problems by using candle, spoon, steel and cooper bar, glass, wood, matches, lamp cable, water, beaker, stand and as it was required in the Student Worksheet. The students were motivated, pleased and highly interested to do observation during the learning process in the class.

b. The students' science process skills in doing experiment also increased at the end of the second meeting of cycle II in which 20 students were motivating and willing to do experiment about Heat Transfer in the daily life. The students were guided by the teachers and they were able to it during the learning process so that they could answers very well the questions contained in the Student Worksheet.

c. The science process skills of communicating was done by 20 students at the end of the cycle II. It could be done actively by the students because they were guided by their teacher so that they were able to communicate the results of their investigations on the applications of the heat transfer on the Student Worksheet and presented the result of their observations in front of the class. This skill needed to be taught to the students so that they could think the examples of the heat transfer applications in everyday life. The teacher also helped the students to draw conclusion appropriately. In the future, students will need to be left alone to think about solving the problem or answering the question asked in the learning activities.

From these results, it can be concluded that all of the science process skills of students studied in this research had corresponded to the indicators set out. It could be concluded that the use of the Problem Based Learning model assisted with Science props could increase the fourth grade students' science process skills.

\section{The Students' Cognitive Learning Outcome}

Cycle II test was conducted after second meeting. The students' learning outcome was shown in Table IV. From the table, it could be seen that the students who passed were $87.0 \%$, or 20 people. The percentage exceeded the specified passed score indicators. Learning science by using the Problem Based Learning model using the Science props successfully improved the students' natural science learning outcome. This could not be separated from the teacher's corrective action efforts taken on the cycle II so that the students became more motivated and active in using their science process skills and understood about the lessons more easily.

The improvement of the students' science process skills in the cycle II helped them to get better learning outcome. It could also not be separated from the number of students who motivated solve the problems and got involved in the spirit of trying to use the Science props in the learning activities of cycle II, who were good at observing the activities performed, and who were active in communicating data. They could easily answer the cycle II's final test because they had observed well, had understood the material being taught, and they were motivated and pleased with the way activity and their teacher taught so that they became eager to follow the lessons. The test's questions were related to what they did in the activities of the first and second meeting in cycle II.

The result of the test in cycle II at third meeting revealed about the students' learning outcome about Heat and Sound Energy and Heat Transfer materials, the number of the students who were able to achieve the Minimum Standard Score, the number of the students who were not able to achieve the Minimum Standard Score, the students' average score and the percentage students' learning mastery classically as follows. 
Table 4. The Students' Cognitive Learning Outcome in Cycle II

\begin{tabular}{|l|l|l|}
\hline No & \multicolumn{1}{|c|}{ Description } & Total \\
\hline 1. & $\begin{array}{l}\text { The number of students who were able to achieve the score } \\
\text { above the Minimum Standard Score }\end{array}$ & 20 \\
\hline 2. & $\begin{array}{l}\text { The number of students who were not able to achieve the } \\
\text { score above the Minimum Standard Score }\end{array}$ & 3 \\
\hline 3. & The students' average score & 83.6 \\
\hline 4. & $\begin{array}{l}\text { The percentage of the students who were able to achieve the } \\
\text { score above the Minimum Standard Score }\end{array}$ & $87.0 \%$ \\
\hline 5. & Target & $75 \%$ \\
\hline
\end{tabular}

Reflection was done after the observation activities. From the results obtained in cycle II and a discussion with the teacher, it was found that it was not necessary to continue the actions in the next cycle because the indicator of success for the science skills, and cognitive learning outcomes had been reached.

\section{CONCLUSION}

Based on the findings and the discussions of the research, it was revealed that the PBL model with the Natural Science props was successfully implemented in the fourth grade of SD Negeri 15 Surau Gadang Siteba Padang through which it could improve the students' science process skill and their cognitive learning achievement in Natural Science. Based on the results of the research, it was concluded that: (1) the fourth grade students' science process skills in doing observation increased from $52.2 \%$ in cycle I to $82.6 \%$ in cycle II, (2) the fourth grade students' science process skills in experimenting increased from $52.2 \%$ in cycle I to $85.2 \%$ in cycle II, (3) the fourth grade students' science process skills in communicating increased from $53.1 \%$ in cycle I to $85.2 \%$ in cycle II, (4) the fourth grade students' cognitive learning achievement increased from $69.6 \%$ in cycle I to $87.0 \%$ in cycle II

\section{REFERENCES}

Hamalik, Oemar.(2013)“Proses belajar mengajar”, Jakarta: Bumi Aksara,.

R. Karban,(2015)"Plant learning and memory," Chicago and London: The University of Chicago Press, pp.31-44,

Depdiknas, (2003).” UU Sisdiknas No. 20”, Jakarta: Depdiknas,

Trianto, (2011) "Mendesain model pembelajaran inovatif-progresif", Jakarta: Kencana Prenada Media Group,.

Susanto, Ahmad. (2013).’Teori belajar dan pembelajaran di Sekolah Dasar”,. Jakarta: Kencana Prenada Media Group,.

Depdiknas, (2006). “Kurikulum Tingkat Satuan Pendidikan”, Jakarta: Depdiknas,

Hosnan, (2014) "Pendekatan Saintifik dan Kontekstual dalam pembelajaran abad 21", Bogor: Ghalia Indonesia,. 